\title{
Integrated Assessment of Farming System Outputs: Lithuanian Case Study
}

\author{
Anastasija Novikova', Lucia Rocchi ${ }^{2}$, Grazina Startiene ${ }^{1}$ \\ ${ }^{1}$ Kaunas University of Technology \\ K. Donelaicio st. 73, LT-44029, Kaunas, Lithuania \\ E-mail.anastasija.novikova@ktu.lt; grazina.startiene@ktu.lt \\ ${ }^{2}$ University of Perugia \\ Borgo XX Giugno 74, 06121 Perugia, Italy \\ E-mail.lucia.rocchi@unipg.it
}

cross $^{\text {ref }}$ http://dx.doi.org/10.5755/j01.ee.31.3.24887

Agriculture provides people with different market outputs. However, market outputs are not the only kind of output provided by agriculture: non-market outputs are produced jointly with the market ones in an agroecosystem. All the outputs produced by agriculture can be classified as the ecosystem services. The magnitude and levels of farming outputs depend on different technologies of production; i.e. different farming systems generate different outputs. Assessing the output of agriculture is quite simple in terms of the market value, but not so easy for non-market outputs. Moreover, evaluation of market and non-market outputs is usually performed separately. The objectives of this paper are to present an integrated evaluation framework for the outputs, marketable and non-marketable, associated with different farming systems. For the case study, we proposed the evaluation of the market and non-market output, associated with milk production in Lithuania, considering both organic and conventional production. In terms of the market evaluation, the results have shown that organic farming produced a value 1.24 times higher than conventional, while the valuation result associated with the non-market output is 83 time higher in organic than in conventional one. The study is the first attempt to develop a framework for integrated evaluation of farming outputs, taking into account market and non-market outputs and considering different types of farming systems.

Keywords: Farming System; Market Outputs; Non-Market Outputs; Conventional Farming; Organic Farming; Milk Production; Lithuania.

\section{Introduction}

Throughout the history, agriculture has played the fundamental role in delivering market outputs such as food and fibre, and as an important economic activity for creation of wealth and employment. Nonetheless, besides its economic role, agriculture provides several other goods and services which are not valuated by the market in spite of their high use value for the society (Novikova et al., 2017). All these market and non-market outputs are produced jointly by agriculture in an agroecosystem (Miskolci, 2008).

As a modified ecosystem, agriculture supports human welfare through various functions and processes known as the ecosystem services (ES) (MEA, 2003, Sandhu et al., 2010), but it is also one of the major beneficiaries of them (Garbach et al., 2014). The ES associated with agriculture have been widely discussed in the literature and can be grouped into the same four categories as the natural ones: provisioning, supporting, regulating and cultural services (MEA, 2003). The provisioning services (production of food, fuel and fibre) and certain cultural services (e.g., recreational activities) are the only categories recognized by the market. Types and intensity of the services can be influenced by the type of farming system. Many forms of environmental degeneration from agriculture such as soil erosion, aquifer deficiency, rangeland deterioration, air pollution, and climate change have huge negative impact on the ecosystem (Makiela \& Misztur, 2012).
Generally, conventional farming supports the society mostly with the provisioning services or market outputs, and is usually considered as a producer of negative impacts (Zhukova et al., 2017; Wagner et al., 2017). Meanwhile, organic farming is usually considered as a provider of supporting and regulating services due to its low input during the production process (Jespersen et al., 2017; Krause \& Machek, 2018), which are usually considered as non-market outputs. These effects are not accounted for in the market and are fairly difficult to quantify. Usually, market farming outputs are evaluated on the basis of statistical data on the micro or macro level, and such an evaluation does not cause any valuation difficulties.

A lot of research has been done on the analysis of the issues of non-market agricultural aspects, usually focusing on evaluation of the benefit or damage by agriculture to the society. Certain research has been dedicated to the analysis of the benefit provided by certain farming systems (Szabo, 2010; Jianjun et al., 2013; Albert et al. 2017, et al.), otherthe value of damage (Pretty et al., 2000; Kubickova, 2004; Wagner et al., 2017 et al.). Other research is dedicated to the identification of the value of particular farming systems effects, as dairy non-market effects (Baskaran et al., 2009a), crops (Christensen, 2011; Takatsuka et al., 2006), olives (Arriaza et al., 2008), pastures (Baskaran et al., 2009b) or focusing on the outputs of organic farming (AldanondoOchoa et al., 2009; Jespersen et al., 2017). Recent research revealed that farming outputs depend on different types of 
Anastasija Novikova, Lucia Rocchi, Grazina Startiene. Integrated Assessment of Farming System Outputs: Lithuanian...

production and intensity. However, the integrated estimation of market and non-market outputs is still rare.

Therefore, the aim of this paper is to present the framework of integrated evaluation of farming outputs, market and non-market, considering conventional and organic systems. The empirical case study is based on the Lithuanian conventional and organic dairy systems. The methods of the research include a comparative literature analysis, direct market valuation and choice experiments techniques.

The paper is structured as follows: first, the general framework for integrated assessment of farming system outputs is presented; second, valuation methods for market and not market outputs used in the current research are described. The research results part presents the empirical research findings on valuation of market and non-market dairy farming system outputs. Conclusions are drawn in the last section of the paper, providing the main points of the framework for integrated evaluation of farming outputs.

\section{Theoretical and Methodological Background}

\section{Integrated Assessment Framework}

An agriculture system produces different outputs, both market, which can be goods (i.e. food, fibre, fuel) or services (i.e. tourism), and non-market ones (i.e. landscape amenities, biodiversity, etc.). All of them represent the agroecosystem services. The level of outputs produced by agricultural system is strictly linked to the type of farming system, either conventional or organic. Organic farming may be characterised by lower yields and would therefore need more land to produce the same amount of food as conventional farms (Seufert et al., 2012). At the same time, in their review, Kremen and Miles (2012) found out that organic farming and diversified farming, compared to conventional farming, support substantially greater biodiversity, soil quality, carbon sequestration, and water-holding capacity in surface soils, energy-use efficiency, and resistance and resilience to climate change. In particular, in terms of conventional monocultures, organic farming systems also enhance the control of weeds, diseases, and arthropod pests, and increase the pollination services. Therefore, considering both market and non-market outputs, it can be affirmed that organic farming system may provide a higher global value according to all the different ecosystem services it provides. To prove it, an integrated valuation is need, as the one proposed in Figure 1.
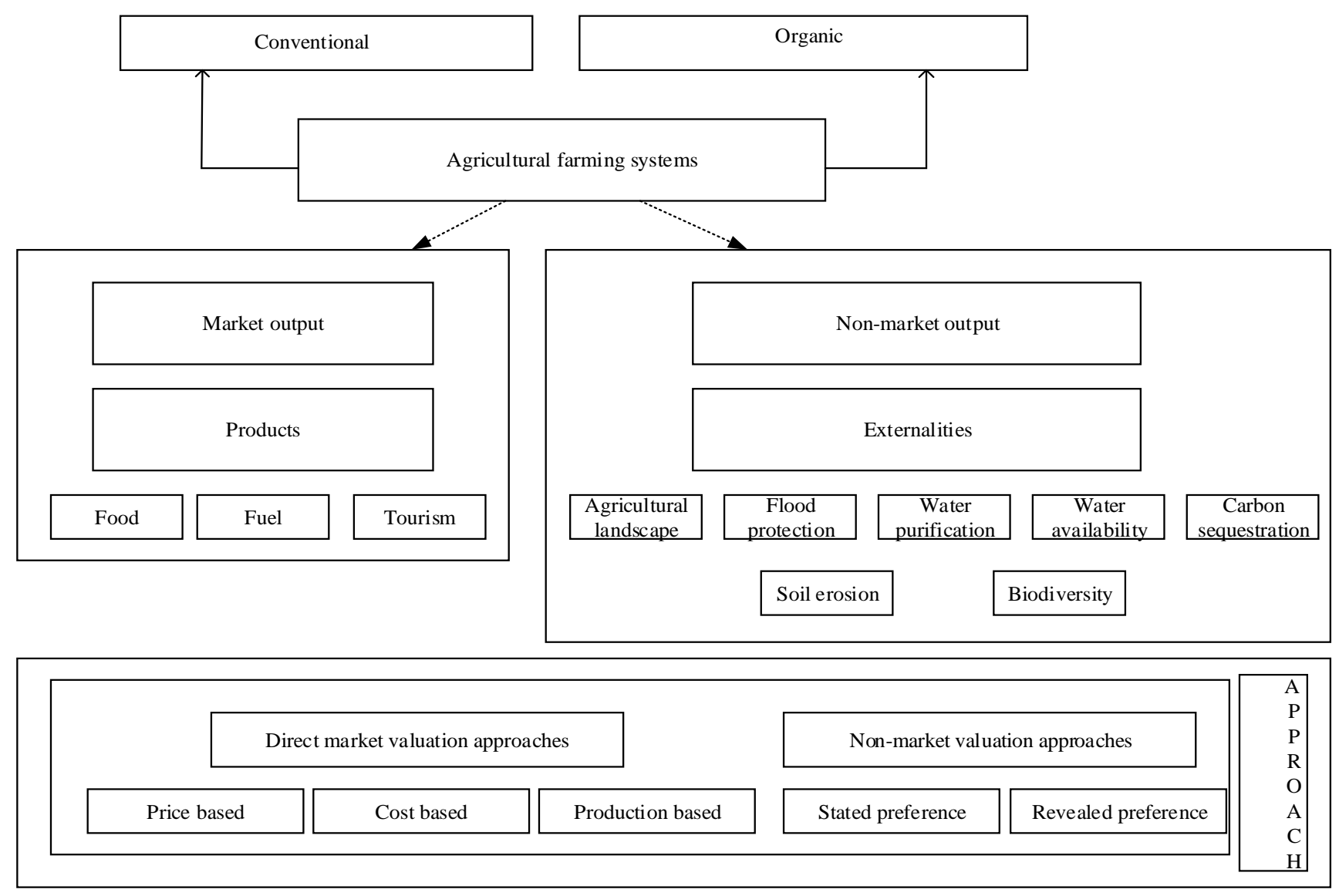

Figure 1. General Framework for Integrated Assessment of Farming System Outputs

The proposed framework accounts for the different outputs of agricultural system, according to both the division between organic and conventional farming and the division between market and non-market outputs. Usually, the different agricultural outputs are evaluated under different methods, on the ground of different types of outputs. Our framework integrates the market and non-market valuation, including both the approaches.

Market farming system outputs are accounted for in the market economy. Hence, direct market valuation approaches (price-based, cost-based and production-based) techniques are used for assessing the market farming system outputs (de 
Groot et al., 2010). These approaches are commonly used to assess the value of the provisioning services, because these goods are usually sold on the real markets. In a wellfunctioning market, the preferences and production costs are reflected in the market price, providing adequate information about the value of goods created in the agroecosystem.

Therefore, the market price could be a good indicator of the value of the ES under the investigation (de Groot et al., 2010). Cost-based approaches usually are employed in case of analysis of the quality of ES, by calculating the farmers' income loss or additional costs incurred, and are associated with environmentally-friendly farming. Production functionbased approaches are used to estimate how much a given ES, usually a regulating service, contributes to the delivery of another service or good which is sold on an existing market (de Groot et al., 2010).

In the absence of market values, the stated preference and revealed preference methods are used for evaluation of nonmarket outputs in agriculture. The revealed preference methods, such as hedonic pricing (HP) and the travel cost method (TCM), are the most commonly employed valuation methods for understanding the economic value in case of amenities which influence the property revenue or with a high recreational value (Schuhmann et al., 2016). The stated preference methods (such as choice experiments and contingent valuation) are known as the universal methods for evaluation of non-market outputs in general and in agriculture specifically (Bateman et al., 2002). Among the stated preference methods, the choice experiments (CE) method is widely applied to estimate non-market goods from farming systems (Jespersen et al., 2017; Jianjun et al., 2013; Aldanondo-Ochoa, Almansa-Saez, 2009; Baskaran et al., 2009ab; et al.). Hypothetical choice scenarios are used for eliciting the respondents' willingness to pay for the goods analysed. The CE are based on Lancaster's Theory of Value (Lancaster, 1966) and the Random Utility Theory (Thurstone 1927). According to Lancaster's Theory of Value, the utilities for goods can be decomposed into individual utilities by their characteristics or attributes, while the Random Utility Theory (RUT) explains the diversity of the opinions in choosing the offered combinations. According to Lancaster, consumers gain their utility not from goods, but rather from the attributes these goods render. According to the RUT, the subject chooses the alternative, which gives the highest utility. Within this theoretical framework, the respondents choose among alternatives according to a utility function with two components: a systematic (i.e. observable) component plus a random term (non-observable by the researcher) (McFadden, 1974).

To provide an example, a case study has been carried out. The aim is to assess the full value associated with a selected agricultural market output and to evaluate the non-market outputs produced with it, and understand the differences in the values produced by organic and conventional farming systems.

\section{Valuation of Market Outputs}

Milk sector has deep traditions in Lithuania. Primary milk production is one of the main branches in agriculture, while milk processing is the most important processing field. The dairy system is an important farming system providing employment to the locals. Lithuanian milk products are sold successfully in foreign markets. As the demand for dairy products is growing, the milk sector has good development prospects in the future. However, due to the sector specifics, external factors, and structural problems tracing back to the past, the milk sector is very vulnerable, and the milk farms are the most state-supported areas of agriculture.

Due to the data issues related to attribution of different farming systems to conventional or organic milk production, the authors were able to use the data about the output - the purchased raw milk (tonne) and prices taking into consideration both the conventional and organic dairy systems. Production and price-based analysis has been employed. The value added in agriculture and income are determined by the volumes of agricultural production and prices. One of the most important indicators in output valuation is the price. Growing purchase prices of agricultural output determine the increase of value added and income (Sapolaite, 2011). Price is one of the important factors, influencing the economic results of farms, especially in the case of organic farms, as they enable the farms to achieve higher prices of agricultural products (Berentsen et al., 2012; Krause and Machek, 2018). Therefore, the purchase prices of selected farming system outputs are analysed.

The data have been taken from the Agricultural Information \& Rural Business Centre (ZŪIKVC), which is the State Enterprise ensuring effective operation of the agricultural information system components. The enterprise has provided the data for the current research, preparing the data separately for conventional and organic milk production. The periods under consideration were 2014-2018, i.e. a fiveyear period, since this period has been taken into consideration by similar research works (Krause and Machek, 2018), and non-market valuation overlaps the five-year period as well.

\section{Valuation of Non-Market Outputs}

Among the several model available for the CE, the present paper employs the Nested Logit (NL) model (Williams, 1977) because of its ability to accommodate differential degrees of interdependence between subsets of alternatives in a choice set (Hensher \& Greene, 2002). For comparison of the results, the general model as multinomial logit (MNL) (Hensher et al., 2005) is employed to see the importance of the choice attributes in explaining consumer preferences towards different options of non-market farming outputs.

In NL model, the observed utility associated to the $k$ th alternative is defined by four parameters associated with the explanatory variables $\beta$, an alternative-specific constant, $\alpha k$, a scale parameter, $\theta$, and the explanatory variables, $\mathbf{x}$ (Hensher and Greene, 2002). Therefore, adding the random component $\left(\varepsilon_{t k}\right)$ the utility of alternative $\mathrm{k}$ for individual $\mathrm{t}$ is:

$U_{t k}=g_{k}\left(\alpha_{k}, \beta^{\prime} x_{t k}, \varepsilon_{t k}\right)=g_{k}\left(V_{t k}, \varepsilon_{t k}\right)=\alpha_{t k}+\beta^{\prime} x_{t k}+\varepsilon_{t k}(1)$

$\operatorname{Var}\left[\varepsilon_{t k}\right]=\vartheta^{2}=k / \theta^{2}$

The scale parameter $(\theta)$, is proportional to inverse of the standard deviation $(\sigma)$ of the random component in the utility expression, and is critical input into the setup of the 
Anastasija Novikova, Lucia Rocchi, Grazina Startiene. Integrated Assessment of Farming System Outputs: Lithuanian...

NL model (Hensher \& Greene, 2002). In our case study, the subsets are represented by the milk farming system (organic and conventional). In this context, the probability of choice among Conventional alternatives is given by:

$$
P(i \mid C)=\frac{e^{V_{i}}}{e^{V_{m i l k 1}}}
$$

where $\mathrm{i}=$ milk1, milk2. Then, it is possible to calculate I, the inclusive value, which is the expected utility from given branch choice:

$$
I_{C}=\ln \left(e^{V_{\text {milk1 } 1}}\right)
$$

At the same time for organic:

$$
\begin{aligned}
& P(i \mid O)=\frac{e^{V_{i}}}{e^{V_{m i l k 2}}} \\
& I_{O}=\ln \left(e^{V_{\text {milk2 } 2}}\right)
\end{aligned}
$$

Then, the model of the choice between farming systems on the basis of the produced ecosystem services is:

$$
P(C)=\frac{e^{\mu\left(\beta^{\prime} C^{+I} C\right)}}{e^{\mu\left(\beta^{\prime} C^{+I} C\right)}+e^{\mu I_{O}}}=\frac{e^{\beta} C^{+\mu I} C}{e^{\beta} C^{+\mu I} C+e^{\mu I} O}
$$

$$
P(O)=\frac{e^{\mu I_{F}}}{e^{\mu\left(\beta^{\prime} C^{+I_{C}}{ }^{2}+e^{\mu I_{O}}\right.}}=\frac{e^{\mu I_{F}}}{e^{\beta} C^{+\mu I_{C}}+e^{\mu I_{O}}}
$$

where, $\mathrm{I}_{\mathrm{C}}$ and $\mathrm{I}_{\mathrm{O}}$ are attributes of the nest conventional and organic, respectively; $\beta_{C}=\mu \beta_{M}$ and $\mu$ are unknown parameters which are to be estimated $(0<\mu \leq 1)$.

A survey based on repetitive choice situations about alternatives of different farming non-market outputs was created and submitted to the Lithuanian sample. The survey is also focused on determining the consumers' attitudes towards and demand for the public goods created in conventional and organic farming systems, considering the livestock and, in particular, milk production. Following the analysis of recent studies (Jianjun et al., 2018; Houessionon et al., 2018; Khanal et al., 2017; Madueira et al., 2013; Goibov et al., 2012; Baskaran, 2009ab; Takatsuka et al., 2006; et al.), and the analysis of Lithuanian agriculture (more

\begin{tabular}{|c|c|}
\hline Attributes (functions of agriculture) & Levels \\
\hline $\begin{array}{c}\text { Scenic views, aesthetic value of the } \\
\text { landscape }\end{array}$ & $\begin{array}{l}\text { - No variety on pastoral farms } \\
\text { - } 10 \% \text { more in scenic views like trees, plantations on pastoral farms } \\
\text { - } 30 \% \text { more in scenic views like trees, plantations on pastoral farms } \\
\end{array}$ \\
\hline Water quality & $\begin{array}{l}\text { - Current ground water pollution due to nitrates and urea } \\
\text { - } 10 \% \text { of the reduction maximum amount of fertilizer permitted (included manure) } \\
\text { - } 20 \% \text { of the reduction maximum amount of fertilizer permitted (included manure); } 30 \% \\
\text { of the reduction maximum amount of fertilizer permitted (included manure) }\end{array}$ \\
\hline Soil erosion & $\begin{array}{l}\cdot \text { No changes } \\
\cdot 10 \% \text { increasing perennial grasslands } \\
\cdot 20 \% \text { increasing perennial grasslands } \\
\cdot 30 \% \text { increasing perennial grasslands } \\
\end{array}$ \\
\hline Biodiversity & $\begin{array}{l}\text { - Using only } 1 \text { race in each farm for type of output } \\
\text { - Using at least } 2 \text { races in each farm for type of output } \\
\text { - Using at least } 3 \text { races in each farm for type of output }\end{array}$ \\
\hline Climate change & $\begin{array}{l}\text { - No change } \\
\text { - Reducing } 10 \% \text { of the total amount of polygrastic herd } \\
\text { - Reducing } 20 \% \text { of the total amount of polygrastic herd }\end{array}$ \\
\hline $\begin{array}{l}\text { Personal contribution/payment (EUR } \\
\text { per year for the next } 5 \text { years) }\end{array}$ & $0,6,12,24,48 \mathrm{EUR} /$ year \\
\hline
\end{tabular}
in Novikova et al., 2018) five attributes have been selected, with the levels representing different farming types, presented in table 1.

Table 1

Selected Attributes and their Levels for Valuation of Non-Market Outputs for Dairy Farming

Five attributes of non-market dairy farming outputs, such as Scenic views and aesthetic value of landscape, water quality soil erosion, biodiversity and climate change, and the cost attribute expressed as personal payment for five years in the future were included to the choice set. To create the choice cards the D-efficient experimental design has been developed using the SAS Studio program. 30 choice cards have been developed and divided randomly into five blocks, each consisting of six sets. These contain five attributes delivered

\begin{tabular}{|c|c|c|c|c|c|}
\hline & ORGANIC-1 & ORGANIC-2 & CONVENTIONAL-1 & CONVENTIONAL-2 & \multirow{5}{*}{$\begin{array}{c}\text { NO } \\
\text { CHOICE }\end{array}$} \\
\hline Landscape & $\begin{array}{c}30 \% \text { more scenic views like } \\
\text { trees, plantations on pastoral } \\
\text { farms }\end{array}$ & $\begin{array}{l}10 \% \text { more scenic views } \\
\text { like trees, plantations on } \\
\text { pastoral farms }\end{array}$ & $\begin{array}{l}\text { No variety on pastoral } \\
\text { farms }\end{array}$ & No variety on pastoral farms & \\
\hline Soil erosion & $\begin{array}{l}20 \% \text { increase in perennial } \\
\text { grasslands }\end{array}$ & $\begin{array}{c}10 \% \text { increase in } \\
\text { perennial grasslands } \\
\text { area }\end{array}$ & $\begin{array}{l}30 \% \text { increase in perennial } \\
\text { grasslands }\end{array}$ & $\begin{array}{l}10 \% \text { increase in perennial } \\
\text { grasslands area }\end{array}$ & \\
\hline $\begin{array}{l}\text { Climate } \\
\text { change }\end{array}$ & $\begin{array}{l}\text { Reducing by } 30 \% \text { the total } \\
\text { amount of polygrastic herd }\end{array}$ & No changes & No changes & $\begin{array}{l}\text { Reducing by } 20 \% \text { the total } \\
\text { amount of polygrastic herd }\end{array}$ & \\
\hline Water quality & $\begin{array}{l}20 \% \text { reduction in the } \\
\text { maximum amount of fertilizer } \\
\text { permitted (included manure) }\end{array}$ & $\begin{array}{l}\text { Current ground water } \\
\text { pollution due to nitrates } \\
\text { and urea }\end{array}$ & $\begin{array}{l}\text { Current ground water } \\
\text { pollution due to nitrates } \\
\text { and urea }\end{array}$ & $\begin{array}{l}10 \% \text { reduction of the maximum } \\
\text { amount of fertilizer permitted } \\
\text { (included manure) }\end{array}$ & \\
\hline
\end{tabular}
at three levels and the cost attribute delivered at four levels (Novikova et al., 2019). The example of the choice card in the dairy questionnaire is shown in Table 2.

Table 2

Example of a Choice Card in the Questionnaire 


\begin{tabular}{|c|c|c|c|c|c|}
\hline & ORGANIC-1 & ORGANIC-2 & CONVENTIONAL-1 & CONVENTIONAL-2 & \\
\hline Biodiversity & $\begin{array}{c}\text { Using only 1 race in each } \\
\text { farm for type of output }\end{array}$ & $\begin{array}{c}\text { Using only 1 race in } \\
\text { each farm for type of } \\
\text { output }\end{array}$ & $\begin{array}{c}\text { Using only 3 races in each } \\
\text { farm for type of output }\end{array}$ & $\begin{array}{c}\text { Using only 2 races in each farm } \\
\text { for type of output }\end{array}$ \\
\hline $\begin{array}{l}\text { Payment for 5 } \\
\text { years in future }\end{array}$ & 48 & 12 & 6 & 24 \\
\hline Your choice & $\square$ & $\square$ & $\square$ & $\square$ & $\square$ \\
\hline
\end{tabular}

\section{Research Results}

\section{Dairy System Market Output Valuation Results}

The milk output share in total agricultural output remained stable during the last five years (2014-2018) and comprised about 18-19\% (Statistics Lithuania, 2018 ${ }^{1}$ ). The main issues related to the negative trends in milk sector were the small purchase prices, and lower direct payments in contrast to crop production (LAEI, 2017²).

According to the data by Statistics Lithuania (2018), in the period 2014-2018, the quantities of dairy cows were decreasing. The decreasing number of dairy cows was determined by lower purchase prices of milk. In 2018, 1515 thousand tons of milk were milked, about $90 \%$ of milk was purchased from milk producers for processing during the analysis period. In comparison to 2017, milk production decreased by $3.5 \%$, compared to 2014 by $15.6 \%$. The number of farms keeping cows decreased by $40 \%$, while the number of cows decreased by $18 \%$ in 2013-2018 (ZŪIKVC, $\left.2019^{3}\right)$.

Dairy farming in the context of ecosystem services provides provisioning services as such as drinking milk and multiple processed products (sour milk, yoghurt and other), at the same time, in case of unsustainable agricultural activities, it contributes to the degradation of several ES such as clean air and water (Baskaran et al., 2009). The environmental impact on regulating and supporting the ES of dairying includes pollution of surface and groundwater; indirect damage to freshwater and habitat through contamination and nutrient pollution of surface and groundwater; loss of native biodiversity; soil erosion, soil contamination, and discharge of greenhouse gases (Clark et al., 2007; Baskaran et al., 2009, et al.). In the case of organic dairy farming, all these impacts on the ES are lower or have a positive effect.

Total raw milk purchased from milk producers decreased by $5 \%$ during the period of the 2014-2018. The quantity of purchased conventional raw milk decreased by $5 \%$ in 2018 compared to 2014, and decreased around $4 \%$ compared to 2017. Meanwhile, the quantity of purchased organic raw milk increased by $78 \%$ in 2018 compared to 2014, and about 36 $\%$ compared to 2017 . The share of organic milk in the total share of raw milk was growing during the period of 20132018 (from $1.27 \%$ in 2013 to $2.39 \%$ in 2018).

During the analysis period, organic farms were increasing in size. According to Nicholas et al. (2014), the increase in size is determined by the aspiration to reach the economies of scale, because bigger farms could easier meet the requirements of organic farming and reach better results in milk production (Skulskis \& Girgzdiene, 2016). This determined better outputs of organic farms in milk production. The decreasing number of conventional milk farms determined the lower milk outputs. The purchase quantities and average prices of organic and conventional milk are presented in Figure 2.

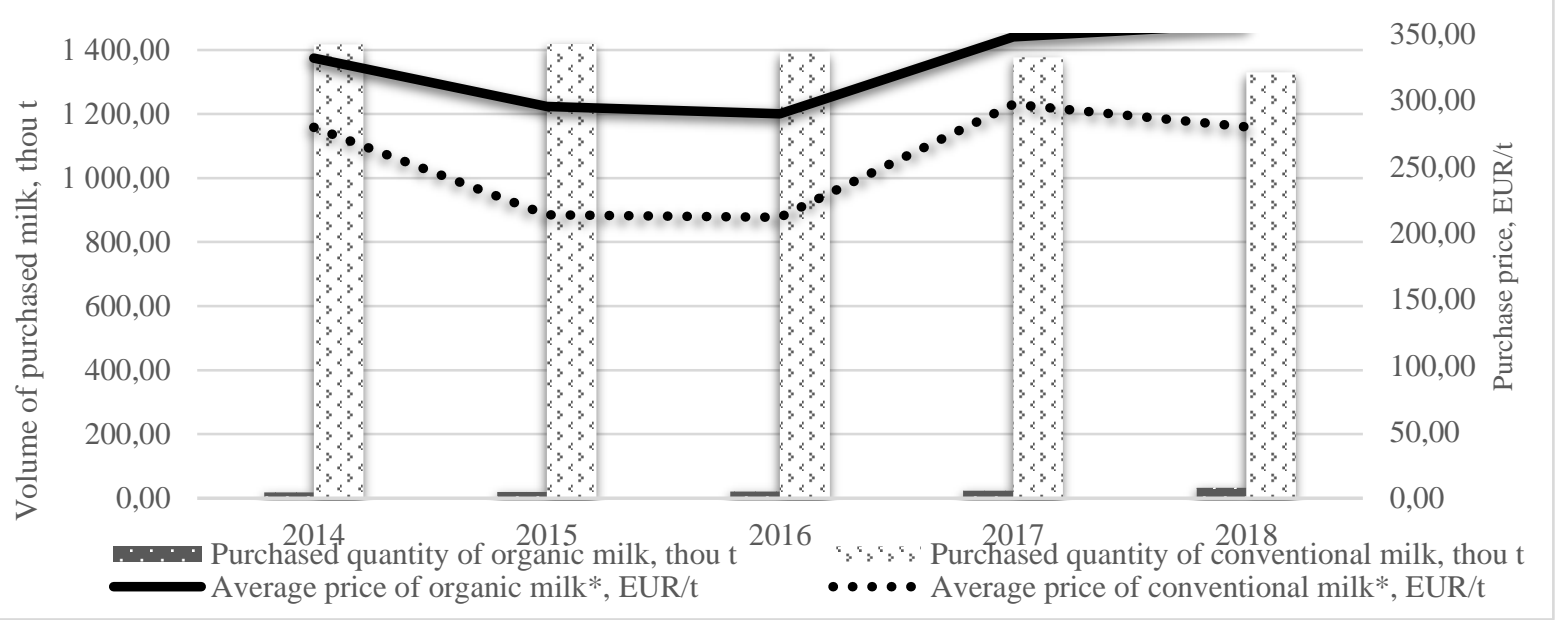

*the weighted average milk price paid to the Lithuanian producers (VAT excluded).

Figure 2. Purchase Quantities and Average Prices of Organic and Conventional Milk (Source: ZŪIKVC (LZŪMPRIS)

During the period of 2014-2018, the average prices of raw organic milk Lithuania paid to the milk producers were changing unevenly. The price of organic milk during the

\footnotetext{
1 According to the data from Statistics Lithuania. https://www.stat.gov.lt/home

2 According to the data from Agriculture and Food Sector in Lithuania. Lithuanian Institute of Agrarian Economics.
}

period of 2014-2018 was on average $28 \%$ higher than the price of conventional raw milk. The average price of organic milk increased by $8 \%$ in 2018 compared to 2014 , while the

\footnotetext{
${ }^{3}$ According to the data from Agricultural Information \& Rural Business Centre.
} 
Anastasija Novikova, Lucia Rocchi, Grazina Startiene. Integrated Assessment of Farming System Outputs: Lithuanian...

price of conventional milk increased by only $0.1 \%$. Compared to 2017, prices of organic milk increased by $3 \%$, and prices of conventional milk decreased by $6 \%$ in 2018 .

Although the production of organic milk accounts for a very small share in the total raw milk; it demonstrated steady growth year by year, as the share of conventional raw milk was decreasing. The higher purchase prices of organic raw milk suggest the increase of value added and income. Therefore, there are all the prerequisites for development of organic raw milk in milk sector. Issues of accounting of organic milk in farms were detected. For example, Skulskis and Girgzdiene (2016) highlighted that the accounting was not sufficient and accurate, because of lack of official data. Due to different issues (such as purchasing issues when the milk is taken from small farms not on a daily), farmers would be selling a part of the milk as conventionally produced (Skulskis \& Girgzdiene, 2016). Moreover, it was found that different sources provided different data on the purchases of milk; therefore, the share of organic milk in total milk production was different (Skulskis \& Girgzdiene, 2016). These issues negatively affect the outputs of organic milk farms, distorting the real data on the organic milk production outputs.

\section{Dairy System Non-Market Output Valuation Results}

The main survey of the CE was carried out in the period between 2018 December and 2019 May. A total of 500 questionnaires were distributed, 239 questionnaires were filled in, 51 questionnaires were eliminated due to incorrect completion of the survey, data from 188 questionnaires have been analysed. A total of 188 valid questionnaires were obtained delivering 564 choice observations. All respondents agreed to answer the questions of the survey, confirming that they would answer them fairly. The survey was implemented in two ways: using face-to-face method randomly by selecting the respondents during seminars and other events; and sending an online questionnaire to the respondents by email. A pre-test of the questionnaire was run in September October 2018 (Novikova et al., 2019).

It should be noted that it was a demonstration study and the first attempt to evaluate both conventional and organic farming system outputs. Therefore, reaching a study sample which could meet the general population characteristic was not considered to be fundamental. Our sample includes more people of young age and with high education than older and non-educated people because of their different willingness to participate in the survey. Approximately about $70 \%$ of the respondents were women; the majority of them belonged to the age group of 18-39, with a 2-people household family structure. About half of the respondents had children. About $70 \%$ of the respondents lived in urban areas, and the monthly net income per person on average was 650 EUR. About $70 \%$ of the respondents had high school education.

The major part of the respondents $(82 \%)$ thought that organic livestock had a positive effect on the natural environment and human wellbeing (only $63 \%$ for conventional). The respondents stated that they were mostly concerned about water quality (about $80 \%$ ), climate change (about $55 \%$ ) and landscape formation (45\%). None of the respondents reported that organic farming had a very negative impact on the natural environment and human wellbeing.

To check the applicability of the framework created for the analysis of consumer preferences towards different nonmarket farming outputs from conventional and organic farming systems, the MNL model and NL were run with NLOGIT 6. The significance of the selected attributes (landscape, soil erosion, climate change, water quality, and biodiversity) was checked during the modelling process. The attribute of the biodiversity was not significant after application of the Wald test (Hensher et al., 2005). Thereby, it was eliminated from the further modelling process. The first model, named MNL model, showed the importance of the choice attributes in explaining consumer preferences towards different options of non-market farming outputs (i.e. landscape, soil erosion, climate change, water quality, and biodiversity). The second model, named NL model, analyses, first, the respondents' opinion in making choices toward organic or conventional farming system, and then the consumers' preferences towards the attributes analysed. The results obtained from the MNL and NL models are presented in Table 3.

Table 3

Results Obtained from MNL and NL Models

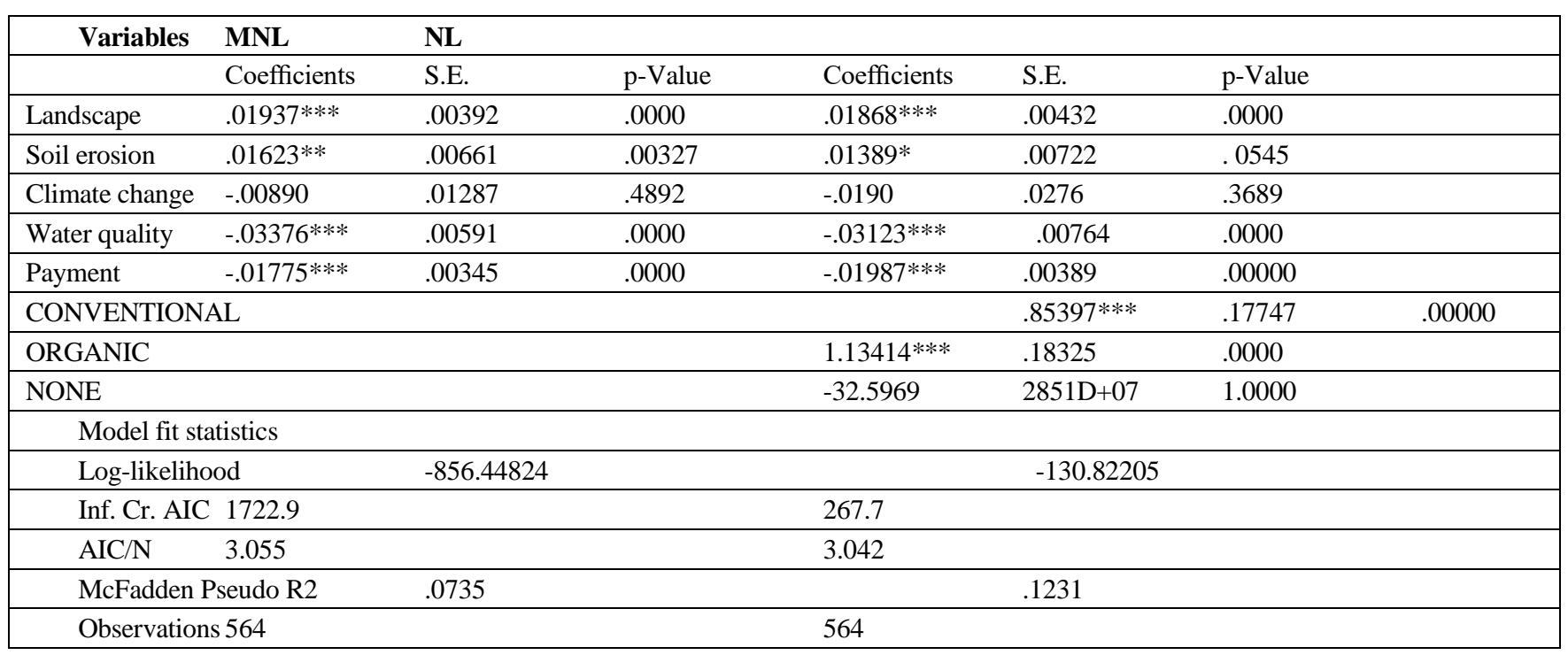


Both in the MNL and NL model, all the attributes are significant except for the climate change attribute; all the signs are expected. Additionally, the NL model shows preference for the organic option over the conventional one (trade-off 1.33). Data provided by the NL model were used for calculation of the value attributed by the respondents to conventional and organic farming in term of the SE. Along with the 5-years production of milk, they were used for calculating the value of the non-market output associated with the milk production. An additional price for ecosystem services produced equal to $0.03 € / 1$ for conventional farming system and $2.17 € / 1$ for organic was obtained. It should be noted that the values produced do not include all the ES associated with milk production, as only the main ones were considered. Moreover, the climate change attribute was not significant, so it further reduced the number of the ES covered by our calculation. It should also be noted that, considering the average price for milk, the market values the organic milk were 1.24 times higher than conventional. However, the related non-market output associated with milk production was 83 time higher in the organic than in the conventional system.

\section{Conclusions}

The main contribution of current research is that the study is the first attempt to develop a framework for integrated evaluation of farming outputs, taking into account market and non-market outputs and considering different types of farming systems. Its scientific significance and practical applicability could be seen as the theoretical background for the created integrated assessment frameworks for evaluation of farming system outputs, taking into account market and non-market outputs. The econometric model for evaluation of non-market agricultural output considering different types of farming systems was also selected during the research study. The Lithuanian dairy sector was taken as a case study for empirical exploration of the framework. Attribute sets with different levels were created specifically for the analysis of dairy sector non-market outputs considering organic and conventional farming. The developed integrated assessment framework for evaluation of farming system outputs is applicable to other countries by using agricultural statistical data for the particular country to conduct empirical research on consumer willingness to pay for agricultural public goods under choice experiments using the attribute set created during the present research.

This study also has its limitations. First, not all farming systems were analysed during the study, but just conventional and organic farming were selected as they covered the majority of the products in agriculture. Moreover, for the both types of farming systems, the research focused on the dairy sector only.

Another limit of the study is related to data collection for market output valuation in relation to the farming systems. Due to the unavailability of the data on the value added, costs and other economic indicators individually for the organic and conventional farming systems, we were able to compare the prices of organic and conventional production as well as the purchased outputs in tonnes. However, despite the lack of the data, we found that the organic milk accounted for a very small share in the total milk production, but its share was growing. Moreover, the prices of organic raw milk were higher than the prices of conventional milk.

Although the sample was not comprehensive in the case of valuation of non-market outputs, the results suggest that there are differences between the organic and conventional farming systems in terms of consumers' willingness to pay. Organic farming seems to be under higher preference in comparison to conventional farming. This preference is registered both by the valuation of market and non-market outputs. However, the market value of the output from organic lower than in case of non-market assessment.

The findings of the current study suggest that there is a need for better data collection, considering the different farming systems, as it could provide more accurate results for valuation of both market and non- market outputs from farming systems.

It should be noted that it is a general framework for evaluation of farming system outputs. The main idea was to expand the overall valuation of market and non-market farming system outputs, emphasizing the need of taking into account the intensity of farming (conventional/organic) and paying attention more on the type of agricultural production. The future research could also consider the European approach for the valuation, instead of just a single country.

\section{Acknowledgement}

This research was supported by 2014-2020 Operational Programme for the European Union Funds Investments in Lithuania: Promotion of Post-Doctoral Fellowships (Contract no. 09.3.3-LMT-K-712-02-0103 DOTSUT-144).

\section{References}

Albert, C.; Schroter-Schlaack, C.; Hansjurgens, B., Dehnhardt, A.; Doring, R. et al. (2017). An economic perspective on land use decisions in agricultural landscapes: Insights from the TEEB Germany Study. Ecosystem Services, 25, 6978. https://doi.org/10.1016/j.ecoser.2017.03.020

Arriaza, M., Gomez-Limon J. A., Kallas, Z., \& Nekhay, O. (2008). Demand for non-commodity outputs from mountain olive groves? Agricultural Economics Review, 9 (1), 5-23.

Aldanondo-Ochoa, A. M., \& Almansa-Saez, C. (2009). The private provision of public environment: consumer preferences for organic production systems. Land Use Policy, 26 (3), 669-682. https://doi.org/10.1016/j.landusepol.2008.09.006 
Anastasija Novikova, Lucia Rocchi, Grazina Startiene. Integrated Assessment of Farming System Outputs: Lithuanian ...

Baskaran, R., Cullen, R., \& Colombo, S. (2009a). Estimating values of environmental impacts of dairy farming in New Zealand. New Zealand Journal of Agricultural Research, 52 (4), 377-389. https://doi.org/10.1080/ 00288230909510520

Baskaran, R., Cullen, R., \& Takatsuka, Y. (2009b). Estimating the value of agricultural ecosystem services: a case study of New Zealand pastoral farming. Australasian Journal of Environmental Management, 16 (2), $103-112$. https://doi.org/10.1080/14486563.2009.9725224

Bateman, I. J., Carson, R. T., Day B., Hanemann, M., Hanley, N., Hett, T., Jones-Lee, M., Loomes, G., Mourato, S., Ozdemiroglu, E., Pearce, D. W., Sugden, R., \& Swanson, J. (2002). Economic Valuation with Stated Preference Techniques: A Manual. Cheltenham: Edward Elgar. https://doi.org/10.4337/9781781009727

Berentsen, P. B. M., Kovacs, K. \& M. A. P. M. van Asseldonk, J. (2012). Comparing risk in conventional and organic dairy farming in the Netherlands: An empirical analysis. Journal of Dairy Science, 95 (7), 3803-3811. https://doi.org/10.3168/jds.2011-5200

Christensen,T., Pedersen, A. B., Nielsen,H. O., Morkbak, M. R., Hasler, B., \& Denver, S. (2011). Primary Determinants of farmers' willingness to participate in subsidy schemes for pesticide-free buffer zones-A choice experiment study. Ecological Economics, 70 (8), 1558-1564. https://doi.org/10.1016/j.ecolecon.2011.03.021

Clark, D. A., Caradus, J. R., Manoghan, R. M., Sharp, P., \& Thorrold, B. S. (2007). Issues and options for future dairy farming in NZ. New Zealand Journal of Agricultural Research, 50 (2), 203-221. https://doi.org/10.1080/ 00288230709510291

De Groot, R. S., Fisher, B., Christie, M., Aronson, J., Braat, L., Haines-Young, R., Gowdy, J., Maltby, E., Neuville, A., Polasky, S., Portela, R. \& Ring, I. (2010). Integrating the ecological and economic dimensions in biodiversity and ecosystem service valuation. Chapter 1. In Kumar, P. (Ed), The Economics of Ecosystems and Biodiversity (TEEB): Ecological and Economic Foundations. London: Earthscan.

Garbach, K, Milder, JC, \& DeClerck, FAJ. (2014). Biodiversity and Ecosystem Services in Agroecosystems. Encyclopedia of Agriculture and Food Systems, 2, 21-40. https://doi.org/10.1016/B978-0-444-52512-3.00013-9

Goibov, M., Schmitz, P. M., Bauer, S., \& Ahmed, M. N. (2012). Application of a choice experiment to estimate farmers preferences for different land use options in Northern Tajikistan. Journal of Sustainable Development, 5(5), 2-16. https://doi.org/10.5539/jsd.v5n5p2

Hensher D. A., Greene W. H. (2002). Specification and estimation of the nested logit model: alternative normalizations. Transportation Research Part B., 36 (1), 1-17. https://doi.org/10.1016/S0191-2615(00)00035-7

Hensher D. A., Rose, J.M., \& Greene W. H. (2005). Applied choice analysis. A primer. Cambridge university press. https://doi.org/10.1017/CBO9780511610356

Houessionon, P., Fonta W. M., Bossa, A. Y., Sanfo S., Thiombiano, N., Zahonogo P., Thomas B. Yameogo T. B., \& Balana B. (2017). Economic valuation of ecosystem services from small-scale agricultural management interventions in Burkina Faso: A discrete choice experiment approach. Sustainability, 9 (9), 1672. https://doi.org/10.3390/su9091672

Jespersen, L. M., Baggesen, D. L., Fog, E., Halsnæs, K., Hermansen, J. E., Andreasen, L., Strandberg, B., Sorensen, J. T., \& Halberg, N. (2017). Contribution of organic farming to public goods in Denmark. Organic Agriculture, 7, $243-266$. https://doi.org/10.1007/s13165-017-0193-7

Jianjun J., Chong J., Thuy T. D., \& Lun, L. (2013). Public preferences for cultivated land protection in Wenling city, China: a choice experiment study. Land Use Policy. 30 (1), 337-343. https://doi.org/10.1016/j.landusepol.2012.04.003

Jianjun, J., Rui H., Wenyu W., \& Haozhou, G. (2018). Valuing cultivated land protection: A contingent valuation and choice experiment study in China. Land Use Policy, 74, 214-219. https://doi.org/10.1016/j.landusepol.2017.09.023

Khanal, U., Wilson C., Managi S., Lee B., Hoang V., \& Gifford, R. (2017). Psychological influence on survey incentives: valuing climate change adaptation benefits in agriculture. Environmental Economics and Policy Studies, 20, $305-324$. https://doi.org/10.1007/s10018-017-0195-4

Krause, J., \& Machek, O. (2018). A comparative analysis of organic and conventional farmers in the Czech Republic. Agric. Econ. - Czech, 64, 1-8. https://doi.org/10.17221/161/2016-AGRICECON

Kremen, C., \& Miles, A. (2012). Ecosystem services in biologically diversified versus conventional farming systems: benefits, externalities and trade-off. Ecology and society 17(4), 40. https://doi.org/10.5751/ES-05035-170440

Kubickova, S. (2004). Non-market evaluation of landscape function of agriculture in the PLA White Carpathians. Agricultural Economics, 50 (9), 388-393. https://doi.org/10.17221/5223-AGRICECON

Lancaster, K. J. (1966). A new approach to consumer theory. Journal of Political Economy, 74 (2), 132157.https://doi.org/10.1086/259131

Madureira, L., Lima Santos, J., Ferreira, A., \& Guimaraes, H. (2013). Feasibility Study on the Valuation of Public Goods and Externalities in EU Agriculture. European Commission. 
Makiela, K., \& Misztur, T. (2012). Going Green versus Economic Performance. Inzinerine Ekonomika-Engineering Economics, 2012, 23 (2), 137-143.https://doi.org/10.5755/j01.ee.23.2.1546

McFadden, D. (1974). Conditional logit analysis of qualitative choice behaviour. In: Zarembka, P. (Ed.), Frontiers in Econometrics. New York: Academic Press: 105-142.

Millennium Ecosystem Assessment (2003). Ecosystem and human well-being: framework for assessment. Washington DC: Island Press, 2003.

Miskolci, S. (2008). Multifunctional agriculture: evaluation of non-production benefits using the Analytical Hierarchy Process. Agric. Econ. - Czech, 54 (7), 322-332.https://doi.org/10.17221/2709-AGRICECON

Nicholas, P. K., Mandolesi, S., Naspetti, S., \& Zanoli, R. (2014). Innovations in low input and organic dairy supply chainsWhat is acceptable in Europe? Journal of Dairy Science, 97 (2), 1157-1167.https://doi.org/10.3168/jds.2013-7314

Novikova, A., Rocchi, L., \& Startiene, G. (2019). Choice Experiment Approach on Evaluation of Non-Market Farming System Outputs: First Results from Lithuanian Case Study. International Scholarly and Scientific Research \& Innovation, 13(5), 706-711.

Novikova, A., Rocchi, L., \& Startiene, G. (2018). Evaluation of farming system outputs in Lithuania: methodological proposal. Zemes ukio mokslai - Agricultural Sciences, 25 (4), 205-215.https://doi.org/10.6001/zemesukiomokslai. v25i4.3871

Novikova, A., Rocchi, R., \& Vitunskiene, V. (2017). Assessing the benefit of the agroecosystem services: Lithuanian preferences using a latent class approach. Land Use Policy, 68, 277-286.https://doi.org/10.1016/ j.landusepol. 2017.07.051

Pretty, J. N., Brett C., Gee D., Hine, R. E., Mason, C. F., Morison, J. I. L., Raven, H., Rayment, M. D., \& van der Bijl, G. (2000). An assessment of the total external costs of UK agriculture. Agricultural Systems 65 (2), 113136.https://doi.org/10. 1016/S0308-521X(00)00031-7

Sandhu, H. S., Wratten, S. D., \& Cullen, R. (2010). Organic agriculture and ecosystem services. Environmental Science and Policy, 13 (1), 1-7.https://doi.org/10.1016/j.envsci.2009.11.002

Szabo, Z. (2010). Evaluation of environmental impacts of crop production, with particular focus on biodiversity External impacts of an intensive farm and an ecological farm. Ph.D. dissertation. Budapest.

Sapolaite, V. (2011). Agricultural gross value added and income of increasing factors. Management theory and studies for rural business and infrastructure development, 4 (28), 127-139.

Schuhmann, P. W., Bass, B. E., Casey, J. F., \& Gill, D. A. (2016). Visitor preferences and willingness to pay for coastal attributes in Barbados. Ocean \& Coastal Management, 134, 240-250.https://doi.org/10.1016/j.ocecoaman. 2016.09.020

Seufert, V., Ramankutty, N., \& Foley, J. A. (2012). Comparing the yields of organic and conventional agriculture. Nature, 485, 229. https://doi.org/10.1038/nature11069

Skulskis, V., \& Girgzdiene, V. (2016). Organic Dairy Supply Chain Development in Lithuania: Research study. Vilnius: Lithuanian institute for agrarian economics. $86 \mathrm{p}$.

Takatsuka, Y., Cullen R., Wilson, M., \& Wratten, S. (2006). Values of Ecosystem Services on Arable Land and the Role of Organic Farming. Paper prepared for the 3rd World Congress of Environmental and Resource Economists. Kyoto, Japan, 3-7 July 2006.

Thurstone, L. (1927). A law of comparative judgement. Psychological Review, 34 (4), 273-286. https://doi.org/10. $1037 / \mathrm{h} 0070288$

Williams H. C. W. L. (1977). On the formation of travel demand models and economic evaluation measures of user benefit. Environment and Planning A: Economy and Space, 9 (3), 285-344. https://doi.org/10.1068/a090285

Wagner, S., Angenendt, E., Beletskaya,O., \& Zeddies, J. (2017). Assessing ammonia emission abatement measures in agriculture: Farmers' costs and society's benefits - A case study for Lower Saxony, Germany. Agricultural Systems, 157, 70-80. https://doi.org/10.1016/j.agsy.2017.06.008

Zhukova, Y., Petrov, P., Demikhov, Y., Mason, A., \& Korostynska, O. (2017). Milk Urea Content and $\delta 13 C$ as Potential Tool for Differentiation of Milk from Organic and Conventional Low-and High-Input Farming Systems. Turkish Journal of Agriculture-Food Science and Technology, 5 (9), 1044-1050. https://doi.org/10.24925/turjaf.v5i9.10441050.1286

The article has been reviewed.

Received in December 2019; accepted in June 2020. 